\title{
Review of the Effects of Drought Stress on Plants: A Systematic Approach
}

\author{
Priyanka Bijalwan'1, Meenakshi Sharma ${ }^{2}$, and Prashant Kaushik ${ }^{3,4^{*}}$ \\ 1 Defence Institute of Bio-Energy Research, DRDO, Pithoragarh, Uttarakhand 262501, India \\ 2 Department of Chemistry, Kurukshetra University Kurukshetra, Kurukshetra 136119, Haryana, India \\ 3 Kikugawa Research Station, Yokohama Ueki, 2265, Kamo, Kikugawa City, Shizuoka 439-0031, Japan \\ 4 Instituto de Conservación y Mejora de la Agrodiversidad Valenciana, Universitat Politècnica de València, \\ 46022 Valencia, Spain \\ * Correspondence: prakau@doctor.upv.es
}

\begin{abstract}
Each year, agriculture suffers critical output losses due to severe drought devastation. Drought stress significantly affects plant physiology, subsequently reducing the crop yield. Drought induces several physiological and molecular changes in plants, the majority of which assist them in adapting to the harsh environment. Drought stress influences plant metabolism both directly and indirectly. Drought-induced stress alters plants' morpho-anatomical, physiological, and biochemical composition, thereby decreasing transpiration and increasing the plants' efficiency to use the stored water. Constant water loss through transpiration results in leaf water deficits. Nonetheless, drought stress has various consequences, ranging from lesions to confusion. Apart from oxidative damage to plants, it may also result in cell death. To mitigate drought's adverse effects, we must first understand how drought affects plant physiology. The purpose of this review is to understand how drought affects plant development by examining the causes and effects of drought-induced stress on plants.
\end{abstract}

Keywords: drought stress; reactive oxygen species; climate change

\section{Introduction}

Plants cultivated in open fields often encounter abiotic stresses throughout their lives, impacting their development and output, especially for longer durations [1]. Drought, one of the significant abiotic stresses, occurs when water potential and turgor are reduced to the point where they impair normal metabolic functions and the plant's reproductive capacity [2]. Drought has been dubbed one of the most severe threats to the environment the world's population faces today $[3,4]$. It is predicted to become more prevalent and severe in many locations due to reduced rainfall and higher evaporation owing to global climate change [5]. Additionally, global warming has led to unpredictable rainfall patterns, resulting in the recurrence of extended drought periods throughout the globe [6, 7]. The continuous radial drought events significantly affect plant development causing growth to be delayed, physiology to be disrupted, and reproduction to be harmed [8-10].

Drought's impact on agriculture is exacerbated by depletion of available water resources and increasing food demand due to the world's alarming population rise [11, 12]. It has been shown that cultivation under drought stress has a molecular, biochemical, physiological, morphological, and ecological impact on plants $[13,14]$. Plants regulate their stomatal aperture (i.e., stomatal conductance (gs)) to control the amount of water lost regulate and optimize $\mathrm{CO}_{2}$ assimilation to avoid photosynthetic inhibition, allowing them to resist water stress $[15,16]$. Stomatal closure works as an early response when water availability becomes a limitation for plant physiological processes, buffering the reduction in xylem water potential and the threat of severe xylem embolism and catastrophic 
hydraulic failure [17, 18]. Moreover, plants use osmotic regulation to lower osmotic potential and overcome adversities caused by water stress. By maintaining turgor pressure, osmotic regulation can help maintain stomatal conductance and moderate water deficit. . When plants are stressed by drought, they can regulate their osmotic balance in three ways: by reducing intracellular water, decreasing cell volume, and increasing cellular contents [19].

Further, the osmotic regulator accumulates a wide range of solutes which are known to function as compatible solutes. They change the osmotic potential of cytoplasm (ten percent of the cell volume) to balance the osmotic potential of the vacuole (ninety percent of the cell volume), protecting and stabilizing proteins and membranes and acting as radical oxygen species scavengers in cells under water stress [20,21]. Proline accumulation is another preventative step done by plants to combat drought stress, according to Ashraf and Foolad [22]. Furthermore, plants respond to water stress by accumulating signal molecules such as abscisic acid (ABA), calcium ( $\mathrm{Ca}^{2+)}$ inositol-1, 4, 5-triphosphate (IP3), and cyclic adenosine 50- ribose -diphosphate (cADPR), etc. [23,24]. ABA plays a pivotal role in connecting the aboveground and underground parts. When plants have water limitations, root cells are the first to sense changes in the environment and release ABA, which is then transmitted to other tissues and organs via vascular bundles, leading to leaf senescence and stomatal closure to avoid water loss. The xylem transports ABA from the ground to above parts of the plant, resulting in higher ABA concentration in the leaves [25].

The chlorophyll content is another critical component affected by drought stress and plays a vital role in photosynthesis. Decrease in chlorophyll content results in reduced plant productivity [26]. However, secondary metabolite production improves when there is a lack of water due to decreased biomass creation and conversion of absorbed $\mathrm{CO}_{2}$ to C-based secondary metabolites [27]. Additionally, drought stress alters the activity of enzymes, impairing the antioxidant process and carbon metabolism. This results in decreased photochemical and enzyme activity in the Calvin cycle, contributing to the process's sluggishness. The disruption of the equilibrium between the generation of reactive oxygen species (ROS) and the capacity of plants to photosynthesize is one of the significant reasons why environmental pressure affects plant growth and photosynthesis capabilities [28]. ROS are naturally occurring byproducts of plant metabolism in their mitochondria, chloroplasts, and peroxisomes in minute quantities [29]. However, when plants are stressed, they produce excessive ROS. Plant cells that generate excessive ROS are harmful to proteins, lipids, and nucleic acids, resulting in cell damage and eventual death [30]. It has been reported that drought stress reduces plant biomass accumulation, partitioning, harvest index, and yield loss, reaching about 70\% [31-33]. Therefore, it is necessary to improve a plant's drought resistance under a range of changing environmental conditions.

\section{Drought effects on different development stages}

Yield loss depends upon which part of the plant is harvested [34]. Drought stress affects different phases of plant growth and development. For instance, water stress is especially critical during reproductive development. Fruits and grains may not grow properly because of rapidly transpiring leaves, which create lower water potentials in the xylem, resulting in water loss in the fruits. Therefore, drought stress has a detrimental effect on plant output and quality, especially during the critical growth periods of the plant (Table 1).

Table 1. Drought stress in its critical phases affects major field and vegetable crops.

\begin{tabular}{cccc}
\hline $\begin{array}{c}\text { Crops } \\
\text { stage }\end{array}$ & Impact of water deficit & Reference \\
\hline
\end{tabular}


Rice Panicle initiation, flag leaf, and Reduction in number of spikelets milky stage per panicle and grain yield

\begin{tabular}{|c|c|c|c|}
\hline Wheat & $\begin{array}{l}\text { Crown root initiation, tillering, } \\
\text { jointing, booting, flowering, } \\
\text { milk and dough stage }\end{array}$ & $\begin{array}{l}\text { Kernel abortion decreased bio- } \\
\text { mass and yield }\end{array}$ & [36] \\
\hline Sorghum & Booting and flowering & $\begin{array}{c}\text { Reduction in yield and quality of } \\
\text { grains }\end{array}$ & [37] \\
\hline Maize & Silking and tasseling & $\begin{array}{c}\text { Delayed silk development, poor } \\
\text { anthesis, reduced silk elongation } \\
\text { and impedes embryo develop- } \\
\text { ment }\end{array}$ & [38] \\
\hline Pearl millet & Booting and flowering & Pollen shedding, reduced yield & [39] \\
\hline Finger millet & Flowering & Yield reduction & {$[40]$} \\
\hline Groundnut & $\begin{array}{l}\text { Peg penetration and pod devel- } \\
\text { opment }\end{array}$ & $\begin{array}{l}\text { Reduced in number and size of } \\
\text { pods }\end{array}$ & {$[41]$} \\
\hline Sunflower & $\begin{array}{l}\text { Head formation and early grain } \\
\text { filling }\end{array}$ & $\begin{array}{l}\text { Depletion in seed yields by re- } \\
\text { ducing seed size and number }\end{array}$ & [42] \\
\hline Sesame & Flowering & $\begin{array}{l}\text { Flower drop, decrease seed yield } \\
\text { and seed oil content }\end{array}$ & [43] \\
\hline Soybean & Flowering and pod filling & $\begin{array}{l}\text { Floral abortion, reduced pod } \\
\text { number, fewer seeds per pod, } \\
\text { and reduced seed size }\end{array}$ & [44] \\
\hline $\begin{array}{c}\text { Blackgram and } \\
\text { Green gram }\end{array}$ & $\begin{array}{l}\text { Flowering and early pod devel- } \\
\text { opment }\end{array}$ & $\begin{array}{l}\text { Decreased seed protein content, } \\
\text { reduced pod size, and seed yield }\end{array}$ & {$[45]$} \\
\hline
\end{tabular}

\begin{tabular}{|c|c|c|c|}
\hline Cotton & $\begin{array}{l}\text { Square formation and boll for- } \\
\text { mation and development }\end{array}$ & $\begin{array}{l}\text { Fewer and smaller bolls reduced } \\
\text { Fiber length and strength }\end{array}$ & [46] \\
\hline Sugarcane & $\begin{array}{c}\text { Cane formation (Up to } 120 \text { days } \\
\text { after sowing) }\end{array}$ & $\begin{array}{c}\text { Low dry matter accumulation } \\
\text { and low sugar yield }\end{array}$ & [47] \\
\hline Potato & $\begin{array}{c}\text { Early growth stage, initiation of } \\
\text { stolon and the formation of tu- } \\
\text { ber }\end{array}$ & $\begin{array}{l}\text { Reduces total leaf area, poor tu- } \\
\text { ber initiation, bulking, and tuber } \\
\text { yield }\end{array}$ & [48] \\
\hline Tomato & $\begin{array}{l}\text { Flowering, fruit growth, matu- } \\
\text { ration and fruit ripening stage }\end{array}$ & $\begin{array}{c}\text { Flower drop, reduced fruit size, } \\
\text { number and quality }\end{array}$ & [49] \\
\hline $\begin{array}{l}\text { Chilli and Cap- } \\
\text { sicum }\end{array}$ & Flowering and fruit set & $\begin{array}{l}\text { Flower and fruit drop, reduction } \\
\text { in dry matter production and nu- } \\
\text { trient uptake }\end{array}$ & [49] \\
\hline Cucumber & $\begin{array}{l}\text { Flowering as well as through- } \\
\text { out fruit development }\end{array}$ & $\begin{array}{l}\text { Male sterility, bitter and de- } \\
\text { formed fruits }\end{array}$ & [50] \\
\hline
\end{tabular}


Leafy vegeta- Throughout growth and devel- Tough leaves, poor leafy growth bles opment and nitrates accumulation

\begin{tabular}{cccc}
\hline Okra & $\begin{array}{c}\text { Flowering and pod develop- } \\
\text { ment }\end{array}$ & Yield loss, fibre development & {$[51]$} \\
\hline Pea & Flowering and pod filling stage & $\begin{array}{c}\text { Poor root nodulation reduced } \\
\text { seed number }\end{array}$ & {$[52]$} \\
\hline $\begin{array}{c}\text { Radish, turnip } \\
\text { and carrot }\end{array}$ & Root enlargement & $\begin{array}{c}\text { Deformed, pungent and poor } \\
\text { root growth, harmful nitrate ac- } \\
\text { cumulation in roots }\end{array}$ \\
\hline
\end{tabular}

When a plant's physical adaptation is no longer adequate to deal with drought, it may react by releasing a range of chemical signals. The molecular signals includes an accumulation of osmolytes, proteins, and genes specifically involved in stress tolerance [53].

\section{Factors responsible for drought}

The disastrous consequences of environmental changes have drastically affected the agricultural systems, including drought. The $\mathrm{CO}_{2}$ concentration has shot upto $400 \mu \mathrm{mol}^{-1}$ in the atmosphere because of large scale deforestation and excessive fossil fuel utilization $[54,55]$. There are many factors responsible for drought:

\subsection{Global warming}

Climate change has become inflicting chaos for a number of agriculture-based ecosystems. From the North to the South Pole, the world is becoming warmer. Since 1906, the average global air temperature has increased by more than 0.9 degrees Celsius [56, 57]. Additionally, as temperature rises, water reservoirs shrink, reducing the amount of water available for agricultural irrigation, a trend that is becoming more pronounced over time. The annual cumulative precipitation has decreased as a result of global warming in a variety of rain-fed agricultural regions throughout the world [58]. Assuming the anticipated increase in air temperature of approximately $2^{\circ} \mathrm{C}$ above current levels by the end of the century, around one-fifth of the world's population would be severely impacted by water scarcity in such a scenario [59]. 


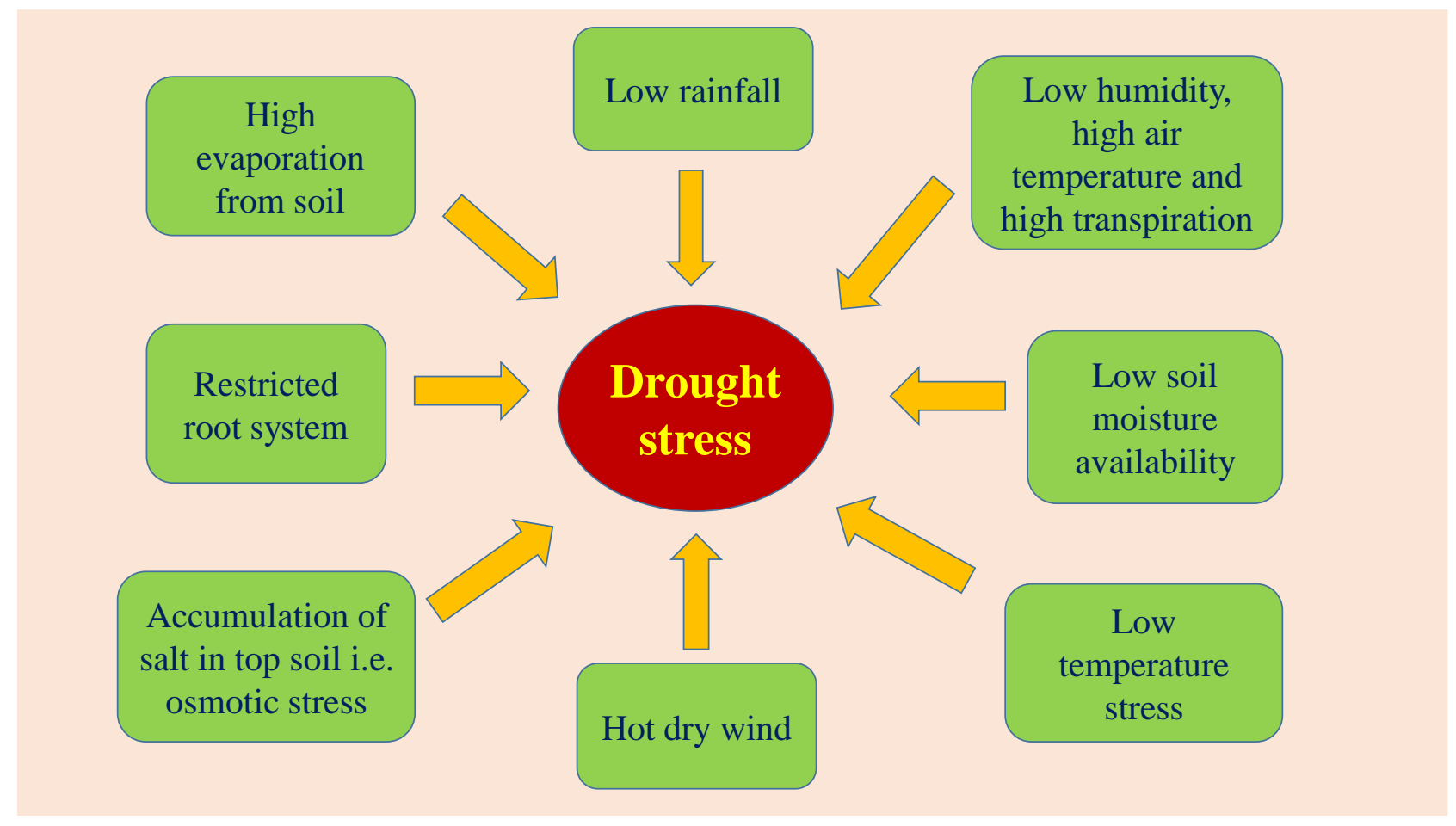

Figure 1. Factors that influence the plant's response to drought stress.

\subsection{Erratic rainfall}

Drought is often seen as a long-term natural disaster occurring primarily in areas where rain falls below normal. A more significant stress level is observed when comparing places where crop production depends entirely on rainfall to areas where the crop is irrigated by canals, rivers, and water channels [60]. During droughts in rain-fed areas, the annual rainfall distribution has a significant effect on water stress [61, 62]. Through their influence on global climate change, three human activities, industrialization, deforestation, and urbanization, have the biggest impact on rainfall patterns and the availability of water to plants. Drought stresses are most often directly connected to the distribution and intensity of rainfall over the course of a year and across years. Global drought conditions have been shown in figure 2 where the map shows 9-month Standardized Precipitation Index (SPI) updated each month with the data for the previous month. The Global Precipitation Climatology Centre (GPCC) monthly precipitation dataset (from 1901-present) is calculated from global station data [63]. 


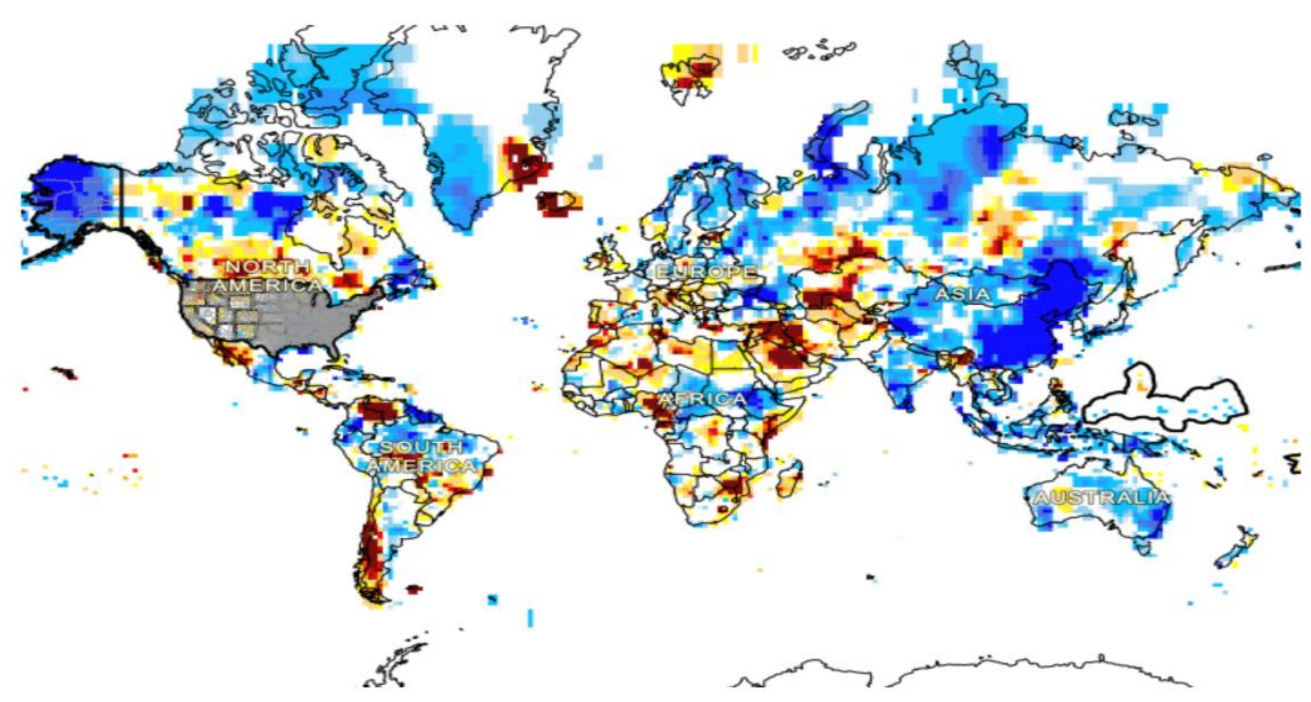

Drought Categories

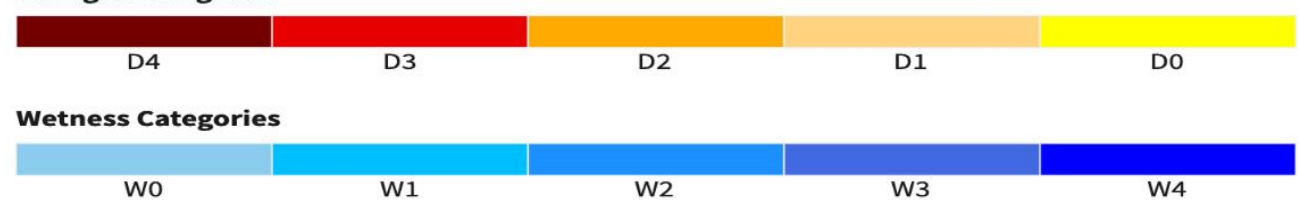

Figure 2. Global drought conditions: monthly SPI (GPCC). The map shows drought categories with the scale D0-D4, with D4 being the most severe level. Further, this map also depicts the wetness categories from W0-W4, with W4 is highest wetness level (Source [63])

\subsection{Changes in the pattern of monsoon}

The monsoon season accounts for a significant portion of rainfall in many parts of the globe, and its incidence is strongly related to the temperature. If current trends continue, summer precipitation in rain-fed areas is anticipated to decline by $70 \%$ by the turn of the twenty-first century $[64,65]$. This will inevitably have a negative effect on agricultural productivity. Surprisingly, more than half of the world's population is food insecure due to significant seasonal rainfall changes induced by monsoon movements [66]. Monsoon rains have had and will continue to affect rhizosphere moisture levels, which in turn influences plant yield through fluctuations in rainfall intensity, frequency, and duration in some parts of the globe [67]. Therefore, crop production needs a shift in agricultural practices due to changing monsoon weather patterns, focusing on sustainable crop production. Crop planning and management are two options for coping with monsoon patterns that swing between insufficient and abundant rainfall and vice versa.

\section{Drought stress effect on plant}

The occurrence of drought affects all phenological stages of plant growth. The effects of drought can be seen at the morphological and molecular levels. The several impacts of drought stress on plants are detailed below:

\subsection{Plant growth and yield}

Seeds cannot absorb and germinate if there is a water shortage since adequate water is required for seed germination [68]. Likewise, sufficient moisture is needed to support a wide range of crops throughout their developmental stages. Drought-induced stress has been reported in some economically essential crops as listed in Table 2.

Table 2. Yield reduction (\%) in various field and vegetable crops under drought stress conditions.

Crop

Average yield reduc-

tion $(\%)$

Reference 


\begin{tabular}{ccc}
\hline Soybean & 58.5 & {$[69]$} \\
\hline Cowpea & 60 & {$[70]$} \\
\hline Chickpea & 57 & {$[71]$} \\
\hline Pigeon pea & 47.5 & {$[72]$} \\
\hline Canola & 30 & {$[73]$} \\
\hline Rice & 72.5 & {$[74]$} \\
\hline Barley & 50 & {$[75]$} \\
\hline Maize & 75 & {$[76]$} \\
\hline Wheat & 22 & {$[77]$} \\
\hline Sorghum & 87 & {$[78]$} \\
\hline Sunflower & 60 & {$[79]$} \\
\hline Potato & 13 & {$[80]$} \\
\hline Tomato & 37.5 & {$[81,82]$} \\
\hline Capsicum & 99 & {$[83$} \\
\hline
\end{tabular}

Cell division and elongation are systematic processes that occur concurrently with growth in plants [84]. Drought during blossoming is frequently associated with infertility [85], owing to a reduction in assimilating flow to the developing ear. Drought stress can significantly reduce production in important field crops by prolonging the anthesis period and delaying grain filling [86]. Numerous factors could explain the decline in yield, including decreased photosynthesis, inefficient flag leaf formation, uneven assimilate portioning, and a depleted pool of critical biosynthesis enzymes such as starch synthase, sucrose synthase, starch enzymes, and -amylase [87]. Drought stress significantly affected barley grain production, as evidenced by decreased tiller counts, spikes, grain per plant, and grain weight. Maize output was reduced due to water scarcity, resulting in delayed silking and a more extended anthesis-to-silking period (Table 1). Drought also reduced soybean seed production globally and at a branch level [88]. Other crops, such as wheat, are impacted as well.

\subsection{Water relation}

Understanding plant-water relations is important to predict the consequences of extreme climatic events such as droughts on the functioning of agricultural systems and the effects of inadequate water supply on plant growth [89]. For instance, drought stress hampers the growth of turfgrass mainly by disrupting plant water relations and its physiological functions [90]. Plants follow different mechanisms to resist drought stress, like reduced water loss through enhanced diffusive resistance, improved water uptake with deep root structures, and reduced water loss via transpiration with smaller succulent leaves [91]. It has been observed that wheat leaf relative water content was greater throughout leaf development and reduced as dry matter accumulated when the leaf matured [92]. Water-use efficiency at the whole-plant level is defined as the ratio of dry matter produced and water consumed [93]. Abbate et al. [94] found that wheat's water-use 
efficiency was higher in limited supplies than in well-watered situations. They linked this improved water efficiency to stomatal closure, which reduces transpiration.

The water loss from plants dramatically affects their water status and metabolic processes [95]. Thus, the high temperature of the ambient atmosphere coupled with low relative humidity favour high transpiration rates. Due to increasing leaf temperature, reduced stomatal conductance was reported in plants with restricted water supply [96, 97]. Drought-stressed plants have dangerously low relative water content and transpiration ratios, causing leaf canopy temperature to rise [98]. They use less water, as measured by the dry matter ratio produced to water absorbed. Drought-tolerant cultivars use water more efficiently than sensitive cultivars [99], whereas susceptible cultivars were insignificant. When water was scarce, wheat used less water than when well-watered. Increased water efficiency is linked to stomatal closure, which reduces transpiration [100, 101]. Therefore, less evapotranspiration due to stomata closure is the primary driver of drought-tolerant cultivars' improved water usage efficiency [102, 103].

\subsection{Nutrient assimilation}

Water shortage reduces total soil nutrient accessibility and root nutrient translocation, resulting in decreasing the ion content of various plant tissues [104]. (For more information, see Table 3.) When plants lack water, their potassium (K) uptake is reduced [105]. Reduced K mobility, slowed transpiration, and impaired root membrane transporter activity contributed to the decrease in K. Drought-stressed Malus hupehensis plants also exhibited reduced K levels [106, 107]. Triticum durum genotypes with high K content were found to be resistant, while genotypes with high sodium $(\mathrm{Na})$ content were found to be susceptible [108]. Dehydration decreases the expression of genes encoding K transporters [109], and CIPK23, a protein kinase that interacts with calcium sensors similarly to calcineurin B, initiates the activation of inner $\mathrm{K}$ channels. The $\mathrm{K}$ channel was suppressed in grapevine roots but active in leaves [110]. While drought-stressed plants, such as peppermint, Spanish sage, Clary sage, and conehead thyme, exhibited no change in leaf nitrogen (N) levels, the $\mathrm{N}$ content of broadleaved lavender and Spanish marjoram plants decreased.

In contrast, the quantity of leaf phosphorus $(\mathrm{P})$ decreased in all species except $S$. sclarea, which remained unchanged [111]. Previously, N deficiency was thought to be the primary cause of the photosynthetic decline and leaf senescence [112]. Further, K levels in Thymus daenensesis, Ocimum basilicum, and Ocimum americanum have been found to drop significantly in the absence of water [113-116].

Table 3. Consequences of drought stress on plant nutrients.

\begin{tabular}{ccc}
\hline Process impacted & Nutrient depletion & Reference \\
\hline Soil integrity by erosion & Every mineral nutrient & {$[117]$} \\
\hline $\begin{array}{c}\text { Transpiration driven mass } \\
\text { flow }\end{array}$ & $\begin{array}{c}\text { Calcium, magnesium, silicon, ni- } \\
\text { trates, and sulfates }\end{array}$ & {$[117]$} \\
\hline Root growth & P and K & {$[118]$} \\
\hline Biological nitrogen fixation & Loss of N & {$[119]$} \\
\hline Soil microbial activity & Loss of N & {$[120]$}
\end{tabular}

\subsection{Photosynthesis}

Water scarcity significantly affects photosynthesis in plants, reducing or completely inhibiting it [121]. When there is a water shortage, photosynthesis is affected because leaf 
area and photosynthesis rate per leaf area decrease [122]. The primary reason for the decline in photosynthetic processes in drought-stricken plants is the loss of $\mathrm{CO}_{2}$ conductance via stomata and mesophyll limitations, which affect Rubisco activity and reduce nitrate reductase and sucrose phosphate synthase activities, along with the ability to produce ribulose bisphosphate (RuBP) (Figure $3 \&$ Table 4). Additionally, it was demonstrated that lack of water reduced leaf area per shoot, resulting in a change in canopy architecture [123]. This change in canopy architecture may affect gas exchange, water relations, vegetative growth, and sink development (e.g., fruits or grains) [124]. The number of kernels and dry weight per 100 kernels of maize decreased as the duration of water stress increased [125]. The amount of chlorophyll, the most fundamental photosynthetic property, is significantly altered by water, serving as a unique indicator of chlorophyll photooxidation and degradation [4]. Reduced plant production has been linked to decreased photosynthetic activity, chlorophyll content, photosystem II photochemical efficiency, stomatal movement, and disturbance of the water status [126, 127].

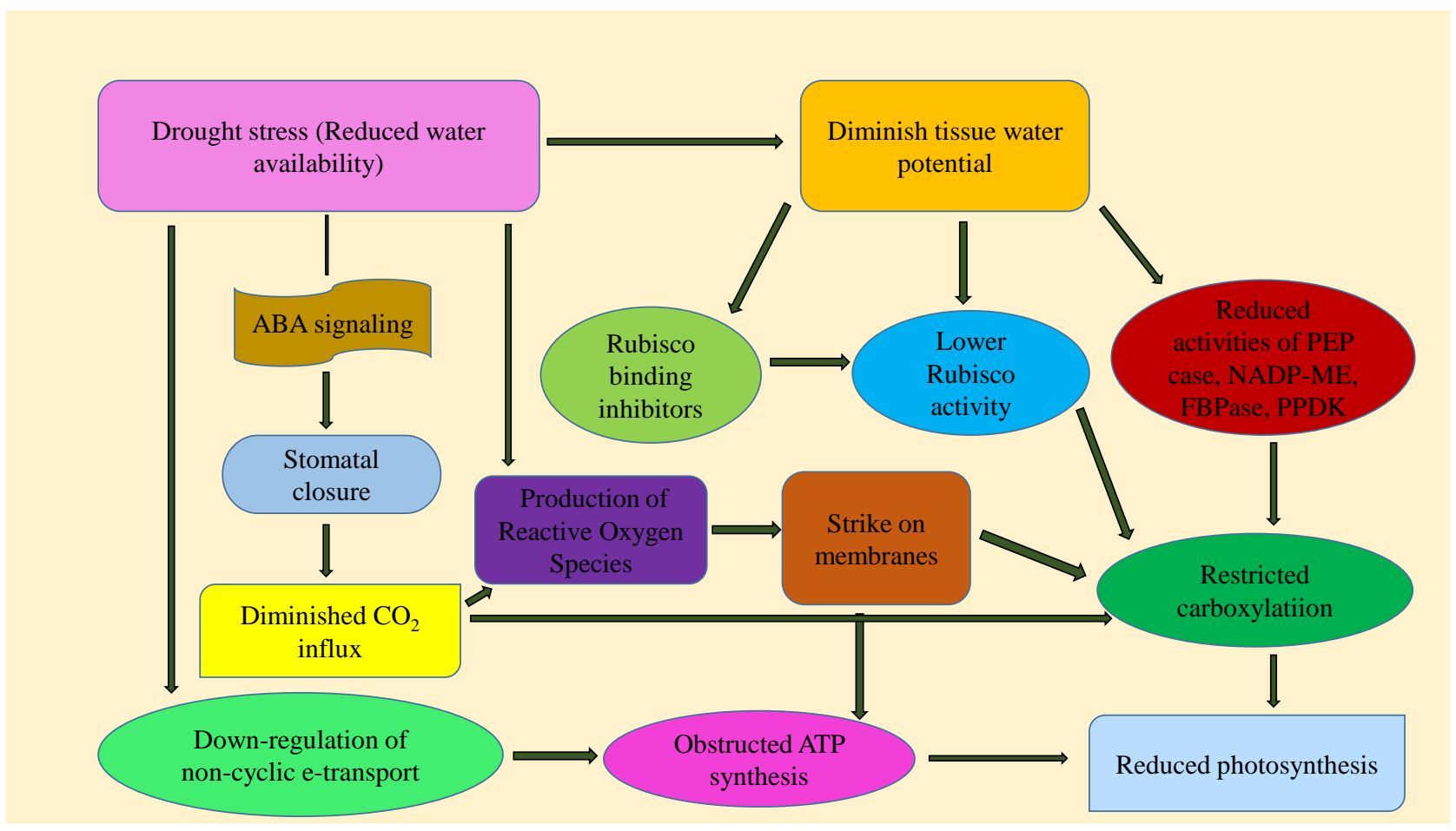

Figure 3. Photosynthesis under water deficit conditions. Photosynthesis is decreased under stress. Water deficit conditions interrupt the balance of ROS production and antioxidant defence, which causes higher production of ROS; such conditions prompt oxidative stress (modified from Farooq et al. [86]).

Table 4. Drought stress affects photosynthetic enzyme activity in various field crops.

\begin{tabular}{cccc}
\hline Crops & Enzyme & Activity & References \\
\hline Maize & PEPCase & Increased & {$[128]$} \\
\hline Alfalfa & Rubisco & Unchanged & {$[129]$} \\
\hline Sugarcane & $\begin{array}{c}\text { Phosphoenolpy- } \\
\text { ruvate carboxylase } \\
\text { (PEPCase), PPDK }\end{array}$ & Reduced & {$[130]$} \\
\hline
\end{tabular}




\section{Tobacco}

Rubisco

Reduced

[131]

Drought stress, for example, reduced physiological, metabolic abnormalities in soybeans by decreasing photosynthetic product output and interfering with the carbon cycle [135]. For example, $\mathrm{O}_{2}^{-}$and $\mathrm{H}_{2} \mathrm{O}_{2}$ generated are important indicators of chlorophyll loss linked with drought stress, eventually resulting in lipid peroxidation and chlorophyll breakdown [132-134]. Drought stress also reduced the abundance of many Calvin cycle proteins in olives, including the down-regulation of Rubisco.

\subsection{Source-sink relationship}

Carbohydrates, the product of photosynthesis, provide a growth and maintenance substrate for non-photosynthetic tissues [136]. Sugar transporters are needed for long-distance carbohydrate allocation in plants and cell sugar partitioning. The practical transport of sugars throughout plant organs via the phloem is the primary mechanism influencing plant development $[137,138]$. Several factors affect sugar transport through the phloem (source, sink, and route between the two), impacting the source-sink interaction [139]. The rate of photosynthesis and the amount of sucrose in leaves affect assimilate export from source to sink [140]. Dry weather reduces photosynthesis and sugar concentration, slowing water transport [141]. Drought also hinders the sink's capacity to utilize assimilates effectively. Drought significantly affects sugar metabolism and phloem loading [142, 143]. As shown in Figure 4, under drought stress, the transcript abundance of gluconeogenic enzymes increases [144, 145]. On the other hand, drought may change nutrient contents (e.g., sugars and amino acids). Drought stress also increases sucrose synthesis in sink organs by inhibiting ADP glucose pyrophosphorylase [146].

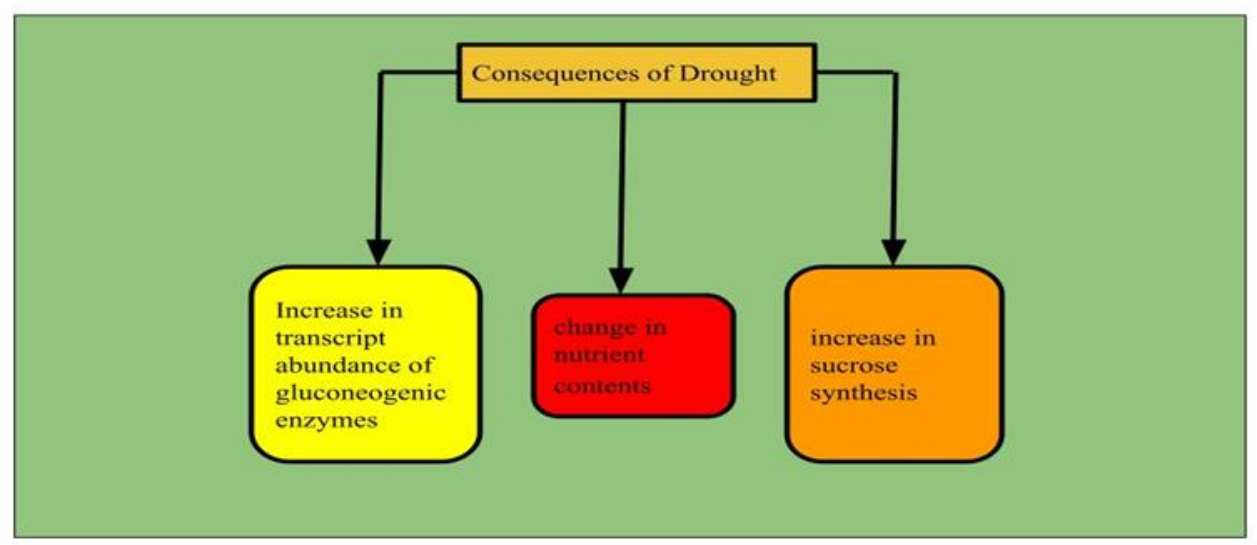

Figure 4. Consequences of drought conditions on plants. The transcript abundance of gluconeogenic enzymes increased, nutrient contents (e.g., sugars and amino acids) changed, and sucrose synthesis increased by inhibiting ADP glucose pyrophosphorylase.

\subsection{Respiration}

Plant respiration is vital for its health and growth because it creates energy and carbon skeletons required for biosynthesis and cell maintenance. Drought stress effects on plant physiology, signalling pathways, gene expression, and photosynthesis have been deliberated broadly, but their effects on respiration are rarely studied [147, 148]. The mitochondrial organelles are responsible for respiration. Apart from disrupting the plant's overall carbon balance, mitochondrial respiration contributes to it, as between $20 \%$ and $80 \%$ of the carbon fixed during photosynthesis is rereleased during the respiration process 
[149]. Carbohydrates lost during respiration affect the metabolic efficiency of the plant [150]. Drought stress alters the electron partitioning between the cytochrome and the cyanide-resistant alternative route, thereby reducing the capacity of ATP to interact with other enzymes [151]. Electrons are transported from ubiquinone to oxygen in plants' mitochondria via two distinct pathways. Moore and Siedow [152] demonstrated that the alternative route differs from the cytochrome routes in that electrons are delivered directly to oxygen via alternative oxidase rather than the other way around. Although it is unknown whether the alternate route contributes to ATP synthesis, it has been demonstrated that it is activated in response to stress or when the primary electron transfer channels are inhibited [153]. When plants are stressed due to a lack of water, they produce ROS, damaging membrane components. In stressed environments, alternative oxidase activity may be beneficial because it maintains normal metabolite levels while minimizing ROS formation [154]. As a result, plants increase their respiration rate under drought-stressed conditions, resulting in an imbalance in the consumption of carbon resources, decreased ATP synthesis, and increased ROS production [155].

The study's findings indicate that regardless of how respiration responds to increased water stress, the ratio of respiration to assimilation (A) frequently increases in response to increased water stress and decreases in response to re-watering [156]. Plant respiration is composed of a variety of temperature-sensitive metabolic activities. Moroney et al. [157] hypothesized that variations in heat response could be a result of changes in substrate availability or changes in energy demand. Despite widespread acceptance that drought has a significant effect on the carbon balance of plants, the metabolic regulation of respiration in response to drought remains an open question [158]. ATP generation is reduced when environmental conditions such as dryness obstruct electron transport along the primary cytochrome-mediated oxidation pathway [159, 160]. Plants have a nonphosphorylating alternative route that enables electrons to be transported directly from ubiquinone to oxygen through another oxidase enzyme under certain conditions [161].

\subsection{Oxidative damage}

Under normal settings, plants produce ROS that are detrimental to the environment. These chemicals are produced spontaneously during plant metabolism and may be detected in various cellular compartments [162], including chloroplasts, peroxisomes, mitochondria, and the plasma membrane. As a result of an uneven oxygen metabolic pathway, the body may accumulate potentially hazardous ROS such as the peroxide anion $\left(\mathrm{O}_{2} \bullet-\right)$, the hydroxyl radical $(\bullet \mathrm{OH})$, and non-radical molecules such as hydrogen peroxide $\left(\mathrm{H}_{2} \mathrm{O}_{2}\right)$ and singlet oxygen $[163,164]$. Due to stress-induced stomatal closure, $\mathrm{CO}_{2}$ uptake in the peroxisome is restricted, resulting in increased photorespiratory $\mathrm{H}_{2} \mathrm{O}_{2}$ generation in the peroxisome and the formation of superoxide and $\mathrm{H}_{2} \mathrm{O}_{2}$ or singlet oxygen in the photosynthetic electron transport chain that is overly reduced $[165,166]$. When there is a drought, it is feasible to increase $\mathrm{ROS}$ production in several ways. Increased $\mathrm{CO}_{2}$ fixation minimizes the amount of NADP+ recyclable through the Calvin cycle, resulting in an over-reduction of the photosynthetic electron transport chain. Drought-stressed plants lose more electrons to $\mathrm{O}_{2}$ during photosynthesis, a process known as the Mehler reaction [167]. As previously documented, the leakage of photosynthetic electrons to the Mehler process is $50 \%$ larger in wheat that has been stressed by drought than in wheat that has not been stressed. Although it is difficult to quantify, it is helpful to compare the amount of ROS produced by the Mehler reaction to the amount produced by photorespiration. Indeed, during drought, the photorespiratory pathway is accelerated, especially when RuBP oxygenation is at its greatest due to $\mathrm{CO}_{2}$ fixation limitations [168]. According to the findings of Noctor et al. [169], photorespiration is expected to provide more than $70 \%$ of total $\mathrm{H}_{2} \mathrm{O}_{2}$ generation under drought circumstances. It is critical to recognize that an increase in ROS generation is highly reactive and has a wide range of cellular, physiological, and biochemical effects [170,171], including disruption of the plasma membrane as shown in Figure 5 
caused by carbohydrate deoxidation, lipid peroxidation, protein denaturation, DNA and RNA destruction, as well as enzyme and pigment degradation [172, 173]. The most severe effects of oxidative stress on plant cells are related to lipid peroxidation and protein denaturation [174, 175]. Some of these processes may produce extra reactive molecules such as ketones, aldehydes, and hydroxyl acids, while others can alter proteins by oxidizing amino acid residues [176]. Protein modifications, including glutathionylation, carbonylation, nitrosylation, and disulfide bond formation, may affect protein function [177]. As a result, crop production and quality decrease [32, 178]. Overexpression of OsCYP21-4 resulted in increased biomass and productivity in rice and a $10-15 \%$ increase in seed weight [179]. CitERF13 overexpression caused fast chlorophyll breakdown and buildup of ROS in the citrus fruit peel of delicious oranges [180, 181]. In Arabidopsis, singlet oxygen $\left({ }^{1} \mathrm{O}_{2}\right)$ overproducing flu and chlorina1 (ch1) have demonstrated that alterations in gene expression may lead to PCD or acclimatization [182].

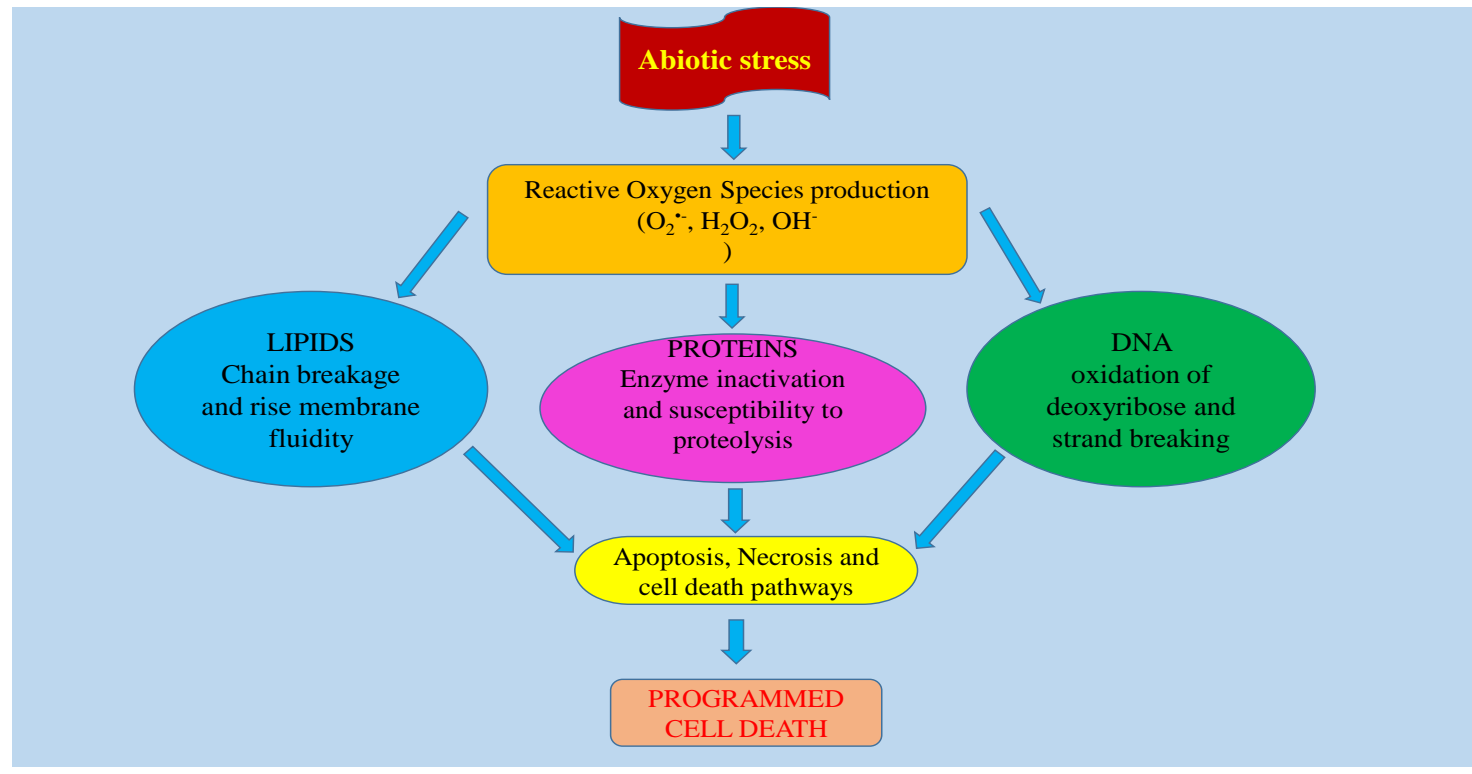

Figure 5. Drought stress disrupts the balance between reactive oxygen species (ROS) and antioxidants (AOX) in plants, resulting in oxidative stress. Oxidative stress can trigger fatal response pathways, leading to programmed cell death (PCD) (modified from Awasthi et al. [172]; Choudhary et al. [173]).

\section{Analysis, Conclusions and Way Forward}

Desert and semi-desert drought alleviation solutions garner more significant attention than other strategies. It has been shown that drought stress may reduce plant growth, development, yield, and biomass. Drought may impact plants' physiological, metabolic, and biochemical activities. Some people employ drought-tolerant plants to combat the consequences of water scarcity. Then it's important to look at how plants might be more flexible and tolerate drought without compromising productivity. When water is limited, breeding improves plant performance and production. Plants lacking water strive to increase transpiration, alter hormones, and postpone senescence. Drought conditions affect plants throughout their life cycle, from germination to harvest. When water is scarce, plant growth and development are delayed, resulting in substantial production losses and in extreme cases, the complete death of cells in their surroundings. Therefore, improving the drought resistance of plants in the face of changing climatic circumstances is a critical problem that must be addressed immediately. Several omics technologies may help plants endure drought, and osmoprotectants (silicon, etc.) may also help plants maintain growth under drought stress. 
Moreover, some plants may become more drought-tolerant by using microorganisms, hydrogel-based nanoparticles, and metabolic engineering. These new methods may help plants produce more food, protecting the world's food supply from drought. Combining cutting-edge technologies such as modern genetics with "OMICS" approaches such as transcriptomics, proteomics, metabolomics, and epigenomics, as well as more traditional approaches such as conventional genetics, has aided in the identification of drought stress-responsive genes involved in ion/osmotic homeostasis, proline/glycine betaine biosynthesis, and detoxification, among other processes. Numerous other approaches, like DNA microarrays, Serial Analysis of Gene Expression, and Differential Display PCR, have been used to validate and confirm the potential involvement of these genes in drought stress adaptation and acclimatization.

Agriculture is being driven into moderately productive regions due to land scarcity, as the world's population continues to expand and consumes more land for housing and industrial operations. As the environment and climate change, plants' stress to grow and survive increases proportionately. Consequently, agricultural research has shifted its focus to improving agricultural productivity in adverse environments. Studying the physiological implications of drought stress on plants becomes critical to understand these effects better and develop stress-resistant breeding lines. When physical adaptations to drought are insufficient, genetic cues like the gene that produces regularity protein may be exploited to boost the efficiency with which water is utilized. The employment of regularity proteins, such as those that control the expression of multiple other genes via crosstalk, to boost the water-use efficiency of roots and leaves may be necessary when a physical adaptation of roots and leaves is insufficient. In response to drought stress, a large number of genes in plants, including transcription factors and short RNAs, are selectively upregulated. However, a significant amount of time and effort is required to adapt to drought stress and the changes in the environment. Improved agronomic practices and more substantial research into drought-resistant plants will be necessary to fulfil future food demand.

Key points

1. The cumulative decrease in annual precipitation due to global warming negatively affects agricultural productivity.

2. The precipitation pattern is changing with more extreme weather projected in the near future.

3. The increased temperatures and changing precipitation patterns are the major drivers of drought, representing the deleterious impacts of climate change on agriculture productivity.

4. The climate-resilient technologies along with improved agricultural practices that are technically and economically feasible must be designed to mitigate the drought effects on plants. Development of drought-resistant varieties will be beneficial to meet rising food demand.

Author Contributions: P.K. conceived of and designed the project; P.K. supervised the study; P.B., M.S. and P.K. wrote the paper; P.K. checked and corrected the final draft. All authors have read and agreed to the published version of the manuscript.

Funding: This research received no external funding.

Institutional Review Board Statement: Not applicable.

Informed Consent Statement: Not applicable.

Data Availability Statement: Not applicable.

Acknowledgements: The authors are thankful to the anonymous reviewers for their careful reading. 
Conflicts of Interest: The authors declare no conflict of interest.

\section{References}

1. Seleiman, M.F.; Al-Suhaibani, N.; Ali, N.; Akmal, M.; Alotaibi, M.; Refay, Y.; Dindaroglu, T.; Abdul Wajid, H.H.; Battaglia, M.L. Drought stress impact on plants and different approaches to alleviate its adverse effects. Plants 2021, 10, 259.

2. Ahmad, P.; Jamsheed, S.; Hameed, A.; Rasool, S.; Sharma, I.; Azooz, M.M.; Hasanuzzaman, M. Drought stress induced oxidative damage and antioxidants in plants. In Book: Oxidative damage to plants. Elsevier. 2014, pp. 345-367.

3. Abbasi, T.; Abbasi, S.A. Biomass energy and the environmental impacts associated with its production and utilization. Renew. Sustain. Energy Rev. 2010, 14, 919-937.

4. Anjum, S.A.; Xie, X.Y.; Wang, L.C.; Saleem, M.F.; Man, C.; Lei, W. Morphological, physiological and biochemical responses of plants to drought stress. Afr. J. Agric. Res. 2011, 6, 2026-2032.

5. Diatta, A.A.; Fike, J.H.; Battaglia, M.L.; Galbraith, J.; Baig, M.B. Effects of biochar on soil fertility and crop productivity in arid regions: A review. Arab. J. Geosci. 2020, 13, 595.

6. O'Connell, E. Towards adaptation of water resource Systems to climatic and socio-economic Chang. Water Resour. Manag. 2017, 31, 2965-2984.

7. Okorie, V.O.; Mphambukeli, T.N.; Amusan, S.O. Exploring the political economy of water and food security nexus in BRICS. Afr. Insight 2019, $48,21-38$.

8. Passioura, J.B.; Angus, J.F. Improving productivity of crops in water-limited environments. In Advances in Agronomy; Academic Press: Cambridge, MA, USA, 2010, 106, pp. 37-75.

9. Daryanto, S.; Wang, L.; Jacinthe, P.A. Global synthesis of drought effects on cereal, legume, tuber and root crops production: A review. Agric. Water Manag. 2020, 179, 18-33.

10. Salehi-Lisar, S.Y.; Bakhshayeshan-Agdam, H. Agronomic Crop Responses and Tolerance to Drought Stress. In Agronomic Crops; Springer: Berlin/Heidelberg, Germany, 2020, pp. 63-91.

11. Gray, S.B.; Brady, S.M. Plant developmental responses to climate Chang. Dev. Biol. 2016, 419, 64-77.

12. Bielach, A.; Hrtyan, M.; Tognetti, V.B. Plants under stress: Involvement of auxin and cytokinin. Int. J. Mol. Sci.2017, 18, 1427.

13. Kaur, G.; Asthir, B. Molecular responses to drought stress in plants. Biol. Plant 2017, 61, 201-209.

14. Raza, A.; Razzaq, A.; Mehmood, S.S.; Zou, X.; Zhang, X.; Lv, Y.; Xu, J. Impact of climate change on crops adaptation and strategies to tackle its outcome: A review. Plants 2019, 8, 34.

15. Torres-Ruiz, J.M.; Diaz-Espejo, A.; Morales-Sillero, A.; Martín-Palomo, M.J.; Mayr, S.; Beikircher, B.; Fernández, J.E. Shoot hydraulic characteristics, plant water status and stomatal response in olive trees under different soil water conditions. Plant Soil 2013, 373, 77-87.

16. Nadal, M.; Flexas, J. Mesophyll conductance to $\mathrm{CO}_{2}$ diffusion: effects of drought and opportunities for improvement. In: García-Tejero IF, Durán-Zuazo VH, eds. Water scarcity and sustainable agriculture in semiarid environment. London: Elsevier, 2018, 404-438.

17. Tardieu, F.; Parent, B.; Simonneau, T. Control of leaf growth by abscisic acid: hydraulic or non-hydraulic processes? Plant Cell Environ. 2010, 33, 636-647.

18. Tombesi, S.; Nardini, A.; Frioni, T. et al. Stomatal closure is induced by hydraulic signals and maintained by ABA in drought-stressed grapevine. Sci Rep. 2015, 5, 12449. https://doi.org/10.1038/srep12449.

19. Osakabe, Y.; Osakabe, K.; Shinozaki, K.; Tran, L.S. Response of plants to water stress. Front. Plant Sci. 2014, 5, 86.

20. Sánchez, F.J.; Manzanares, M.; de Andres, E.F.; Tenorio, J.L.; Ayerbe, L. Turgor maintenance, osmotic adjustment and soluble sugar and proline accumulation in 49 pea cultivars in response to water stress. Field Crops Research, 1998, 59, 225-235.

21. Bohnert, H.J.; Shen, B. Transformation and compatible solutes. Scientia Hortic. 1999, 78, 237-260.

22. Ashraf, M.; Foolad, M.R. Roles of glycine betaine and proline in improving plant abiotic stress resistance. Environ. Exp. Bot. 2007, 59, $206-216$.

23. Kumar, M.; Kesawat, M.S.; Ali, A.; Lee, S.C.; Gill, S.S.; Kim, H.U. Integration of abscisic acid signaling with other signaling pathways in plant stress responses and development. Plants 2019, 8, 592. 
24. Yang, X.; Lu, M.; Wang, Y.; Wang, Y.; Liu, Z.; Chen, S. Response Mechanism of Plants to Drought Stress. Horticulturae 2021, 7, 50. https://doi.org/10.3390/ horticulturae7030050.

25. McAdam,S.A.; Sussmilch, F.C.; Brodribb, T.J. Stomatal responses to vapour pressure deficit are regulated by high speed gene expression in angiosperms. Plant, cell and environment 2016, 39, 485-491.

26. Muller, B.; Pantin. F.; Génard, M.; Turc, O.; Freixes, S.; Piques, M. Water deficits uncouple growth from photosynthesis, increase C content, and modify the relationships between C and growth in sink organs. J. Exp. Bot. 2011, 621715-172910.

27. Selmar, D.; Kleinwächter, M. Stress enhances the synthesis of secondary plant products: The impact of stress-related over-reduction on the accumulation of natural products. Plant Cell Physiol. 2013, 54, 817-826.

28. Rani, A.; Devi, P.; Jha, U.C.; Sharma, K.D.; Siddique, K.H.M.; Nayyar, H. Developing Climate-Resilient Chickpea Involving Physiological and Molecular Approaches with a Focus on Temperature and Drought Stresses. Front. Plant Sci. 2020, 10, 1759.

29. Gill, S.S.; Tuteja, N. Reactive oxygen species and antioxidant machinery in abiotic stress tolerance in crop plants. Plant Physoil Biochem. 2010, 12, 909-30.

30. You, J.; Chan, Z. “ROS regulation during abiotic stress responses in crop plants,". Frontiers in Plant Sci. 2015, 6, 1092.

31. Wu, C.; Cui, K.; Wang, W.; Li, Q.; Fahad, S.; Hu, Q.; Huang, J.; Nie, L.; Mohapatra, P.K.; Peng, S. Heat-induced cytokinin transportation and degradation are associated with reduced panicle cytokinin expression and fewer spikelets per panicle in rice. Front Plant Sci. $2017,8,371$.

32. Naeem, M.; Muhammad, S.N.; Rashid, A.; Muhammad, Z.I.; Muhammad, Y.A.; Yasir, H.; Fahad, S. Foliar calcium spray confers drought stress tolerance in maize via modulation of plant growth, water relations, proline content and hydrogen peroxide activity. Arch Agron Soil Sci. 2017, 1, 1.

33. Fahad, S.; Bajwa, A.A.; Nazir, U.; Anjum, S.A.; Farooq, A.; Zohaib, A.; Sadia, S.; Nasim, W.; Adkins, S.; Saud, S.; Ihsan, M.Z.; Alharby, H.; Wu, C.; Wang, D.; Huang, J. Crop production under drought and heat stress: plant responses and management options. Front Plant Sci. $2017,8,1147$.

34. Comas, L.H.; Becker, S.R.; Cruz, V.M.V.; Byrne, P.F.; Dierig, D.A. Root traits contributing to plant productivity under drought. Front Plant Sci. 2013, 4, 442 .

35. Pascual, V.J.; Wang, Y. Impact of Water Management on Rice Varieties, Yield, and Water Productivity under the System of Rice Intensification in Southern Taiwan. Water 2017, 9, 3; doi:10.3390/w9010003.

36. Haseem, J.M.; Wondimu, T.; Borena, F.R.; Kebede, N.; Niguse, A.; Hailu, E.K. Wheat response to water stress condition at different growth stage in Amibara, Ethiopia. African J Agric Res. 2019, 14, 1493-1498.

37. Shenkut, A.; Tesfaye, K.; Abegaz, F.; Hordofa, T. Determination of water requirement and crop coefficient for Sorghum (Sorghum bicolor L.). East African J Sci. 2013, 7, 41-50.

38. Udom, B.E.; Kamalu, O.J. Crop water requirements during growth period of maize (Zea maya L.) in a moderate permeability soil on coastal plain sands. Int J Plant Res. 2019, 1, 1-7.

39. Zegada-Lizarazu, W.; Lijima, M. Deep root water uptake ability and water use efficiency of pearl millet in comparison to other millet species. Plant Production Sci. 2005, 8, 454-460.

40. Tadele, Z. Drought adaptation in millets. In Book: Abiotic stress in plants- recent advances and future perspectives. 2016, DOI:10.5772/61929.

41. Roja, M.; Navatha, N.; Devender, Reddy M.; Deepthi, Ch. Estimation of Crop Water Requirement of Groundnut Crop Using FAO CROPWAT 8.0 Model. Agro Economist - An Int J. 2020, 7, 35-40.

42. Yawson, D.O.; Bonsu, M.; Armah, F.A.; Afrifa, E.K.A. Water requirement of sunflower (Helianthus annus L.) in a tropical humid-coastal Savanna zone. ARPN J Agric Biol Sci. 2011, 6, ISSN 1990-6145.

43. Sarkar, A.; Sarkar, S.; Zaman, A.; Rana, S.K. Performance of summer sesame (Sesamum indicum) under different irrigation regimes and nitrogen levels. Ind J Agron. 2010, 55, 143-146.

44. Singh, R.; Singh, K.; Bhandarkar, D.M. Estimation of water requirement for soybean (Glycine max) and wheat (Triticum aestivum) under vertisols of Madhya Pradesh. Ind J Agric Sci. 2013, 84, 190-7.

45. Baroowa, B.; Gogoi, N. Biochemical changes in black gram and green gram genotypes after imposition of drought stress. J Food Legume. 2014, 27, 350-353. 
46. Wang, R.; Ji, S.; Zhang, P.; Meng, Y.; Wang, Y.; Chen, B.; Zhou, Z. Drought effects on cotton yield and fiber quality on different fruiting branches. Crop Sci. 2016, 56, 1265-1276.

47. Verma, I.J.; Das, H.P.; Ghanekar, M.G. A study of water requirement of sugarcane (Saccharum officinarum L.) in gangetic plains. MAUSAM. 2004, $55,339-344$.

48. Obidiegwu, J.; Bryan, G.; Jones, G.; Prashar, A. Coping with drought: stress and adaptive responses in potato and perspectives for improvement. Front. Plant Sci. 2015, 6, 542.

49. Bahadur, A.; Chatterjee, A.; Kumarm, R.; Singh, M.; Naik, P.S. Physiological and biochemical basis of drought tolerance in vegetables. Veg. Sci. 2011, 38, 1-16.

50. Kemble, J.K.; Sanders, D.C. Basics of vegetable crop irrigation. Alabama Co-operative Extension System ANR-1169. 2000.

51. Konyeha, S.; Alatise, M.O. Evapotranspiration and leaf area index (LAI) of irrigated okra (Abelmoschus esculentus L. Moench) in Akure, SouthWestern city of Nigeria. Int. J. Engineer Res Tech. 2013, 2: ISSN: 2278-0181.

52. Maingi, S.; Ndiiri, J.; Mati, B. Estimation of crop water requirements for garden pea, sweet pepper and tomato using the crop WAT model in Maragua watershed, Murang'a county, Kenya. Int J Agric Sci. 2020, 5, 112-123.

53. Goufo, P.; Moutinho-Pereira, J.M.; Jorge, T.F.; Correia, C.M.; Oliveira, M.R.; Rosa, E.A.S. Cowpea (Vigna unguiculata L. Walp.) metabolomics: osmoprotection as a physiological strategy for drought stress resistance and improved yield. Front. Plant Sci. 2017, 8:586.

54. Yin, J.; Gentine, P.; Zhou, S.; Sullivan, S.C.; Wang, R.; Zhang, Y.; Guo, S. Large increase in global storm runoff extremes driven by climate and anthropogenic changes. Nat. Commun. 2018, 9, 1-10.

55. Yang, H.; Huntingford, C.; Wiltshire, A.; Sitch, S.; Mercado, L. Compensatory climate effects link trends in global runoff to rising atmospheric $\mathrm{CO}_{2}$ concentration. Environ. Res. Lett. 2019, 14, 124075.

56. Brown, S.; Nicholls, R.J.; Lázár, A.N.; Hornby, D.D.; Hill, C.; Hazra, S.; Addo, K.A.; Haque, A.; Caesar, J.; Tompkins, E.L. What are the implications of sea level rise for a $1.5,2$ and $3^{\circ} \mathrm{C}$ rise in global mean temperatures in the Ganges-Brahmaputra-Meghna and other vulnerable deltas? Regul. Environ. Chang. 2018, 18, 1829-1842.

57. Cook, B.I.; Smerdon, J.E.; Seager, R.; Coats, S. Global warming and 21 ${ }^{\text {st }}$ century drying. Clim. Dyn. 2014, 43, $2607-2627$.

58. Warner, K.; Afifi, T. Where the rain falls: Evidence from 8 countries on how vulnerable households use migration to manage the risk of rainfall variability and food insecurity. Clim. Dev. 2014, 6, 1-17.

59. Ray, D.K.; West, P.C.; Clark, M.; Gerber, J.S.; Prishchepov, A.V.; Chatterjee, S. Climate change has likely already affected global food production. PLoS ONE 2019, 14, 217148.

60. Maliva, R.; Missimer, T. Aridity and drought. In: Arid Lands Water Evaluation and Management, Environmental Science and Engineering (Environmental Engineering), Springer: Berlin, Germany, 2012, pp. 21-39.

61. Konapala, G.; Mishra, A.K.; Wada, Y.; Mann, M.E. Climate change will affect global water availability through compounding changes in seasonal precipitation and evaporation. Nat. Commun. 2020, 11, 1-10.

62. Fatima, A.; Farid, M.; Safdar, K.; Fayyaz, A.; Ali, S.M.; Adnan, S.; Nawaz, M.; Munir, H.; Raza, N.; Zubair, M. Loss of Agro-Biodiversity and Productivity Due to Climate Change in Continent Asia: A Review. In: Plant Eco physiology and Adaptation under Climate Change: Mechanisms and Perspectives, Springer: Berlin/Heidelberg, Germany, 2020, pp. 51-71.

63. GPCC (The Global Precipitation Climatology Centre), available online on https://www.drought.gov/international, accessed on 12/10/21.

64. Ali, N.; Anjum, M.M. Drought Stress: Major Cause of Low Yield and Productivity. Austin Environ. Sci. 2016, 1, 10-12.

65. Reddy, P.P. Impacts of climate change on agriculture. In Climate Resilient Agriculture Ensuring Food Security; Springer: Berlin/Heidelberg, Germany, 2015, pp. 43-90.

66. Guo, H.D.; Zhang, L.; Zhu, L.W. Earth observation big data for climate change research. Adv. Clim. Chang. Res.2015, 6, 108-117.

67. Aryal, J.P.; Sapkota, T.B.; Khurana, R.; Khatri Chhetri, A.; Jat, M.L. Climate change and agriculture in South Asia: Adaptation options in smallholder production systems. Environ. Dev. Sustain. 2020, 22, 5045-5075.

68. Kaya, M.D.; Okçu, G.; Atak, M.; Cıkıll, Y.; Kolsarıcı, Ö. Seed treatments to overcome salt and drought stress during germination in sunflower (Helianthus annuus L.). Europ J Aagron. 2006, 24, 291-295. 
69. Samarah, N.H.; MullenM R.E.; Cianzio, S.R.; Scott, P. Dehydrin- like proteins in soybean seeds in response to drought stress during seed filling. Crop Sci. 2006, 46, 2141-50

70. Ogbonnaya, C.I.; Sarr, B.; Brou, C.; Diouf, O.; Diop, N.N.; Roy-Macauley, H. Selection of cowpea genotypes in hydroponics, pots, and field for drought tolerance. Crop Sci. 2003, 43, 1114-20.

71. Nayyar, H.; Kaur, S.; Singh, S.; Upadhyaya, H.D. Differential sensitivity of Desi (small-seeded) and Kabuli (large- seeded) chickpea genotypes to water stress during seed filling: effects on accumulation of seed reserves and yield. J Sci Food Agr. 2006, 86, $2076-2082$.

72. Nam, N.H.; Chauhan, Y.S.; Johansen, C. Effect of timing of drought stress on growth and grain yield of extra-short- duration pigeonpea lines. J Agr Sci. 2001, 136, 179-89.

73. Sinaki, J.M.; Heravan, E.M.; Rad, A.H.S.; Noormohammadi, G.; Zarei, G. The effects of water deficit during growth stages of canola (Brassica napus L.). Amer. Euras J Agri Environ Sci. 2007, 2, 417-422.

74. Lafitte, H.R.; Yongsheng, G.; Yan, S.; Li1, Z.K. Whole plant responses, key processes, and adaptation to drought stress: the case of rice. J. Exp. Bot. 2007, 58, 169-75.

75. Samarah, N.H. Effects of drought stress on growth and yield of barley. Agron. Sustain. Dev. 2005, 25, 145-149.

76. Kamara, A.Y.; Menkir, A.; Badu-Apraku, B.; Ibikunle, O. The influence of drought stress on growth, yield and yield components of selected maize genotypes. J. Agr Sci. 2003, 141, 43-50.

77. Tack, J.; Barkley, A.; Nalley, L.L. Heterogeneous effects of warming and drought on selected wheat variety yields. Clim. Chang. 2014,125, 489500.

78. Craufurd, P.Q.; Peacock, J.M. Effect of heat and drought stress on Sorghum (Sorghum biocolor) II. Grain yield. Experi. Agric. 2008, 29, 77-86.

79. Mazahery-Laghab, H.; Nouri, F.; Abianeh, H.Z. Effects of the reduction of drought stress using supplementary irrigation for sunflower (Helianthus annuus) in dry farming conditions, Pajouheshva- Sazandegi. Agron. Hort. 2003, 59, 81-86.

80. Kawakami, J.; Iwama, K..; Jitsuyama, Y. Soil water stress and the growth and yield of potato plants grown from microtubers and conventional seed tubers. Field Crop. Res. 2006, 95, 89-96.

81. Patanè, C.; Tringali, S.; Sortino, O. Effects of deficit irrigation on biomass, yield, water productivity and fruit quality of processing tomato under semi-arid Mediterranean climate conditions. Sci. Hortic. 2011, 129, 590-596.

82. Pires, R.C.D.M.; Furlani, P.R.; Ribeiro, R.V.; Junior, D.B.; Sakai, E.; Lourenção, A.L.; Neto, A.T. Irrigation frequency and substrate volume e_ects in the growth and yield of tomato plants under greenhouse conditions. Sci. Agric. 2011, 68, 400-405.

83. Showemimo, F.A.; Olarewaju, J.D. Drought Tolerance Indices in Sweet Pepper (Capsicum annuum L.). Int. J. Plant Breed. Genet. 2007, 1, 29-33.

84. Fathi, A.; Tari, D.B. Effect of drought stress and its mechanism in plants. Int. J. Life Sci. 2016, 10, 1-6.

85. Zandalinas, S.I.; Sales, C.; Beltrán, J.; Gómez-Cadenas, A.; Arbona, V. Activation of secondary metabolism in citrus plants is associated to sensitivity to combined drought and high temperatures. Front. Plant Sci. 2017, 7, 1954.

86. Farooq, M.; Wahid, A.; Kobayashi, N.; Fujita, D.; Basra, S.M.A. Plant drought stress: effects, mechanisms and management. Agronomy of sustainable development, Springer Verlag, Germany 2009, 29, 185-212.

87. Plaut, Z. Plant exposure to water stress during specific growth stages, Encyclopedia of Water Science, Taylor \& Francis 2003, pp. 673-675.

88. Frederick, J.R.; Camp, C.R.; Bauer, P.J. Drought-stress effects on branch and main stem seed yield and yield components of determinate soybean. Crop Sci. 2001, 41, 759-763.

89. Lambers, H., Oliveira, R.S., 2019. Plant water relations, in: Plant Physiological Ecology. Springer, pp. 187-263.

90. Saud, S., Li, X., Chen, Yang, Zhang, L., Fahad, S., Hussain, S., Sadiq, A., Chen, Yajun, 2014. Silicon application increases drought tolerance of Kentucky bluegrass by improving plant water relations and morphophysiological functions. The Scientific World Journal 2014.

91. Farooq, M., Hussain, M., Wahid, A., Siddique, K.H.M., 2012. Drought stress in plants: an overview. Plant responses to drought stress 1-33.

92. Siddique, M.R.B.; Hamid, A.; Islam, M.S. Drought stress effects on water relations of wheat. Bot. Bull. Acad. Sinica 2001, 41, 35-39.

93. Monclus, R.; Dreyer, E.; Villar, M.; Delmotte, F.M.; Delay, D.; Petit, J.M.; Barbaroux, C.; Thiec, D.L.; Brechet, C.; Brignolas, F. Impact of drought on productivity and water use efficiency in 29 genotypes of Populus deltoids x Populus nigra. New Phytol. 2006, 169, 765-777.

94. Abbate, P.E.; Dardanellib, J.L.; Cantareroc, M.G.; Maturanoc, M.; Melchiorid, R.J.M.; Sueroa, E.E. Climatic and water availability effects on wateruse efficiency in wheat. Crop Sci. 2004, 44, 474- 483. 
95. Mannocchi, F.; Todisco, F.; Vergni, L. Agricultural drought: Indices. Definition and analysis. In: Rodda JC, Ubertini L, EDITORS. The Basic of Civilization-Water Science? Proceedings of the UNESCO/IAHS/IWIIA Symposium. Rome, Italy: IAHS Publ. 2004, 286, $246-254$.

96. Verslues, P.E.; Agarwal, M.; Katiyar-Agarwal, S.; Zhu, J.; Zhu, J.K. Methods and concepts in quantifying resistance to drought, salt and freezing, abiotic stresses that affect plant water status. Plant J. 2006, 45, 523-539.

97. Kögler, F.; Söffker, D. Water (stress) models and deficit irrigation: System-theoretical description and causality mapping. Ecol. Model. 2017, 361, $135-156$.

98. Kutlu, N.; Terzi, R.; Tekeli, C.; Senel, G.; Battal, P.; Kadioglu, A. Changes in anatomical structure and levels of endogenous phytohormones during leaf rolling in Ctenanthesetosa. Turkish J. Biol. 2009, 33, 115-122.

99. Lambers, H.; Chapin, F.S., III; Pons, T.L. Plant Physiological Ecology; Springer: New York, NY, USA, 2008.

100. Khalid, M.F.; Hussain, S.; Ahmad, S.; Ejaz, S.; Zakir, I.; Ali, M.A.; Ahmed, N.; Anjum, M.A. Impacts of Abiotic Stresses on Growth and Development of Plants. In Plant Tolerance to Environmental Stress; CRC Press: Boca Raton, FL, USA, 2019, pp. 1-8.

101. Du, Y.; Zhao, Q.; Chen, L.; Yao, X.; Zhang, W.; Zhang, B.; Xie, F. Effect of drought stress on sugar metabolism in leaves and roots of soybean seedlings. Plant PhysiolyBiochem. РPВ 2020, 146, 1-12.

102. Kumawat, K.R.; Sharma, N.K. Effect of Drought Stress on Plants Growth. Popular Kheti 2018, 6, $239-241$.

103. Sharma, A.; Wang, J.; Xu, D.; Tao, S.; Chong, S.; Yan, D.; Li, Z.; Yuan, H.; Zheng, B. Melatonin regulates the functional components of photosynthesis, antioxidant system, gene expression, and metabolic pathways to induce drought resistance in grafted Carya cathayensis plants. Sci. Total Environ.2020, 713, 136675.

104. Kheradmand, M.A.; Fahraji, S.S.; Fatahi, E.; Raoofi, M.M. Effect of water stress on oil yield and some characteristics of Brassica napus. Int. Res. J. Basic Appl. Sci. 2014, 8, 1447-1453.

105. Hu, Y.; Schmidhalter, U. Drought and salinity: A comparison of their effects on mineral nutrition of plants. J. Plant Nutr. Soil. Sci. 2005, 168, 541549 .

106. Hu, L.; Wang, Z.; Huang, B. Effects of cytokinin and potassium on stomatal and photosynthetic recovery of Kentucky bluegrass from drought stress. Crop Sci. 2013, 53, 221-231.

107. Qi, J.; Sun, S.; Yang, L.; Li, M.; Ma, F.; Zou, Y. Potassium uptake and transport in apple roots under drought stress. Hortic. Plant J. 2019, 5, 10-16.

108. Karimpour, M. Effect of Drought Stress on RWC and Chlorophyll Content on Wheat (Triticum durum L.) Genotypes. World. Ess. J. 2019, 7, 52-56.

109. Li, Y.; Sun, C.; Huang, Z.; Pan, J.; Wang, L.; Fan, X. Mechanisms of progressive water deficit tolerance and growth recovery of Chinese maize foundation genotypes Huangzao 4 and Chang 7-2, which are proposed on the basis of comparison of physiological and transcriptomic responses. Plant Cell Physiol. 2009, 50, 2092-2111.

110. Cuéllar, T.; Pascaud, F.; Verdeil, J.L.; Torregrosa, L.; Adam-Blondon, A.F.; Thibaud, J.B.; Sentenac, H.; Gaillard, I. A grapevine Shaker inward $\mathrm{K}^{(+)}$channel activated by the calcineurin B-like calcium sensor 1-protein kinase CIPK23 network is expressed in grape berries under drought stress conditions. Plant J. 2010, 61, 58-69.

111. Garcia-Caparros, P, Romero MJ, Llanderal A, Cermeno P, Lao MT, Segura ML. Effects of drought stress on biomass, essential oil content, nutritional parameters and costs of production in six Laminacease species. Water 2019, 11, 573.

112. Da Silva, E.C.; Nogueira, R.J.M.C.; da Silva, M.A.; de Albuquerque, M.B. Drought stress and plant nutrition. Plant Stress $2011,5,32-41$.

113. Bahreininejad, B.; Razmjou, J.; Mirza, M. Influence of water stress on morpho-physiological and phytochemical traits in Thymus daenensis. Int. J. Plant Prod. 2013, 7, 151-166.

114. Khalid, K.A. Influence of water stress on growth, essential oil, and chemical composition of herbs (Ocimum sp.). Int. Agrophys. 2006, 20, 289-296.

115. Sarani, M.; Namrudi, M.; Hashemi, S.M.; Raoofi, M.M. The effect of drought stress on chlorophyll content, root growth, glucosinolate and proline in crop plants. Intl. J. Farm. Alli. Sci. 2014, 3, 994-997.

116. Samarah, N.; Mullen, R.; Cianzio, S. Size distribution and mineral nutrients of soybean seeds in response to drought stress. J. Plant Nutr. 2004, $27,815-835$.

117. Barber, S. A. Soil Nutrient Bioavailability: A Mechanistic Approach 2nd Edn New York, NY: Wiley. 1995.

118. Lynch, J.P.; Brown, K.M. Topsoil foraging-an architectural adaptation of plants to low phosphorus availability. Plant Soil 2001, 237, 225-237. 
119. Ladrera, R.; Marino, D.; Larrainzar, E.; Gonzalez, E.M.; Arrese-Igor, C. Reduced carbon availability to bacteroids and elevated ureides in nodules, but not in shoots, are involved in the nitrogen fixation response to early drought in soybean. Plant Physiol. 2007, 145, 539-546.

120. Schimel, J.; Balser, T.C.; Wallenstein, M. Microbial stress response physiology and its implications for ecosystem function. Ecology 2007, 88, 13861394.

121. Nezhadahmadi, A.; Prodhan, Z.H.; Faruq, G. Drought tolerance in wheat. Sci. World J. 2013, 610721.

122. Bhargava, S.; Sawant, K. Drought stress adaptation: Metabolic adjustment and regulation of gene expression. Plant Breed. 2013, $132,21-32$.

123. Deepak, S.B.; Thakur, A.; Singh, S.; Bakshi, M.; Bansal, S. Changes in crop physiology under drought stress: A review. J. Pharmacogn. Phytochem. 2019, 8, 1251-1253.

124. Rahmati, M.; Mirás-Avalos, J.M.; Valsesia, P.; Lescourret, F.; Génard, M.; Davarynejad, G.H.; Bannayan, M.; Azizi, M.; Vercambre, G. Disentangling the effects of water stress on carbon acquisition, vegetative growth, and fruit quality of peach trees by means of the Quali Tree model. Front. Plant Sci. 2018, 9, 3.

125. Ge, T.; Sui, F.; Bai, L.; Tong, C.; Sun, N. Effects of water stress on growth, biomass partitioning, and water-use efficiency in summer maize (Zea mays L.) throughout the growth cycle. Acta Physiol. Planta 2012, 34, 1043-1053.

126. Rahdari, P.; Hosseini, S.M.; Tavakoli, S. The studying effect of drought stress on germination, proline, sugar, lipid, protein and chlorophyll content in purslane (Portulaca oleracea L.) leaves. J. Med. Plants Res. 2012, 6, 1539-1547.

127. Xiang, D.B.; Peng, L.-X.; Zhao, J.L.; Zou, L.; Zhao, G.; Song, C. Effect of drought stress on yield, chlorophyll contents and photosynthesis in tartary buckwheat (Fagopyrum tataricum). J. Food Agric. Environ. 2013, 11, 1358-1363.

128. Jeanneau, M.; Gerentes, D.; Foueillassar, X.; Zivy, M.; Vidal, J.; Toppan, A. Improvement of drought tolerance in maize: towards the functional validation of the Zm-Asr1 gene and increase of water use efficiency by over-expressing C4-PEPC. Biochimie. 2002, 84, 1127-1135.

129. Medrano, H.; Parry, M.A.J.; Socias, X.; Lawlor, D.W. Long-term water stress inactivates Rubisco in subterranean clover. Ann. Appl. Biol. 1997, $131,491-501$.

130. Du, Y.C.; Kawamitsu, Y.; Nose, A.; Hiyane, S.; Murayama, S.; Wasano, K. Effects of water stress on carbon exchange rate and activities of photosynthetic enzymes in leaves of sugarcane (Saccharum Sp.). Aust. J. Plant Physiol. 1996, 23, 719-726.

131. Parry, M.A.J.; Andralojc, P.J.; Khan, S.; Lea, P.J.; Keys, A.J. Rubisco activity: effects of drought stress. Ann. Bot. 2002, 89, 833-839.

132. Abid, G.; M’hamdi, M.; Mingeot, D.; Aouida, M.; Aroua, I.; Muhovski, Y.; Sassi, K.; Souissi, F.; Mannai, K.; Jebara, M. Effect of drought stress on chlorophyll fluorescence, antioxidant enzyme activities and gene expression patterns in faba bean (Vicia faba L.). Arch. Agron. Soil Sci. 2017, 63, $536-552$.

133. Gurumurthy, S.; Sarkar, B.; Vanaja, M.; Lakshmi, J.; Yadav, S.; Maheswari, M. Morpho-physiological and biochemical changes in black gram (Vigna mungo L. Hepper) genotypes under drought stress at flowering stage. Acta Physiol. Plant 2019, 41, 42.

134. Du, Y.; Zhao, Q.; Chen, L.; Yao, X.; Zhang, W.; Zhang, B.; Xie, F. Effect of drought stress on sugar metabolism in leaves and roots of soybean seedlings. Plant Physiol. Biochem.PPB 2020, 146, 1.12.

135. Abdallah, M.B.; Trupiano, D.; Polzella, A.; De Zio, E.; Sassi, M.; Scaloni, A.; Zarrouk, M.; Youssef, N.B.; Scippa, G.S. Unraveling physiological, biochemical and molecular mechanisms involved in olive (Olea europaea L. cv. Chétoui) tolerance to drought and salt stresses. J. Plant Physiol. 2018, 220, 83-95.

136. Van Ittersum, M.K., Cassman, K.G. Yield gap analysis-rationale, methods and applications-Introduction to the special issue. Field Crops Res. 2013, $143,1-3$.

137. Zhao, B.; Ma, B.L.; Hu, Y. Source-Sink Adjustment: A Mechanistic Understanding of the Timing and Severity of Drought Stress on Photosynthesis and Grain Yields of Two Contrasting Oat (Avena sativa L.) Genotypes. J. Plant Growth Regul. 2021, 40, $263-276$.

138. Fischer, R.A.; Byerlee, D.; Edmeades, G.O. Crop Yields and Global Food Security: Will Yield Increase Continue to Feed the World? ACIAR Monograph No. 158. Canberra: Australian Centre for International Agricultural Research. 2014.

139. Korner, C. Paradigm shift in plant growth control. Curr. Opin. Plant Biol. 2015, 25, 107-114.

140. Yu, S.M.; Lo, S.F.; Ho, T.D. Source-sink communication: regulated by hormone, nutrient, and stress cross-signaling. Trends Plant Sci. 2015, 20, 844-857. 
141. Penella, C.; Landi, M.; Guidi, L.; Nebauer, S.G.; Pellegrini, E.; San Bautista, A. Salt-tolerant rootstock increases yield of pepper under salinity through maintenance of photosynthetic performance and sinks strength. J. Plant Physiol. 2016, 193, 1-11.

142. Lemoine, R.; La Camera, S.; Atanassova, R.; Dédaldéchamp, F.; Allario, T.; Pourtau, N. Source-to-sink transport of sugar and regulation by environmental factors. Front. Plant Sci. 2013, 4, 272.

143. White, A.C.; Rogers, A.; Rees, M.; Osborne, C.P. How can we make plants grow faster? A source-sink perspective on growth rate. J. Exp. Bot. 2016, $67,31-45$.

144. Cramer, G.R.; Ergul, A.; Grimplet, J.; Tillett, R.L.; Tattersall, E.A.; Bohlman, M.C. Water and salinity stress in grapevines: early and late changes in transcript and metabolite profiles. Funct. Integr. Genomics 2007, 7, 111-134.

145. Taji, T.; Ohsumi, C.; Iuchi, S.; Seki, M.; Kasuga, M.; Kobayashi, M. Important roles of drought and cold-inducible genes for galactinol synthase in stress tolerance in Arabidopsis thaliana. Plant J. 2002, 29, 417-426.

146. Suphia Rafique. Drought Responses on Physiological Attributes of $<\mathrm{em}>$ Zea mays $</ \mathrm{em}>$ in Relation to Nitrogen and Source-Sink Relationships [Online First], Intech Open, (November 20th 2020). DOI: 10.5772/intechopen.93747.

147. Sanhueza, C.; Bascunan-Godoy, L.; Corcuera, L.J.; Turnbull, M.H. The response of leaf respiration to water stress in Nothofagus species. New Zealand J. Bot. 2013, 51, 88-103.

148. Bowling, D.R.; McDowell, N.G.; Bond, B.J.; Law, B.E.; Ehleringer, J.R. C-13 content of ecosystem respiration is linked to precipitation and vapor pressure deficit. Oecologia 2002, 131, 113-124.

149. Xu, Z.; Jiang, Y.; Zhou, G. Response and adaptation of photosynthesis, respiration and antioxidant systems to elevated $\mathrm{CO}_{2}$ with environmental stress in plants. Front. Plant Sci. 2015. https://doi.org/10.3389/fpls.2015.00701.

150. Lavania, D.; Dhingra, A.; Siddiqui, M.H.; Al-Whaibi, M.H.; Grover, A. Current status of the production of high temperature tolerant transgenic crops for cultivation in warmer climates. Plant Physiol. Biochem. 2015, 86, 100-108.

151. Singh, A.; Agrawal, M. Effects of ambient and elevated $\mathrm{CO}_{2}$ on growth, chlorophyll fluorescence, photosynthetic pigments, antioxidants, and secondary metabolites of Catharanthus roseus (L.) G Don. grown under three different soil N levels. Environ. Sci. Poll. Res. Int. 2015, 22, 39363946.

152. Moore, A.L.; Siedow, J.N. The regulation and nature of the cyanide resistant oxidase of plant mitochondria, Biochim. Biophys. Acta 1991,1059, 121140.

153. Wanger, A.B.; Moore, A.L. Structure and function of the plant alternative oxidase: its putative role in the oxygen defence mechanism, Bioscience Rep. 1997, 17, 319-142.

154. Blokhina, O.; Virolainen, E.; Fagerstedt, K.V. Antioxidants, oxidative damage and oxygen deprivation stress: a revies, Ann.Bot. 2003, 91, 179-194.

155. Baxter, A.; Mittler, R.; Suzuki, N. ROS as key players in plant stress signalling. J. Exp. Bot. 2014, 65, 1229-1240.

156. Ayub, G.; Zaragoza-Castells, J.; Griffin, K.L.; Atkin, O.K. Leaf respiration in darkness and in the light under pre-industrial, current and elevated atmospheric $\mathrm{CO}_{2}$ concentrations. Plant Sci. 2014, 226, 120-130.

157. Moroney, J.V.; Jungnick, N.; DiMario, R.J.; Longstreth, D.J. Photorespiration and carbon concentrating mechanisms, two adaptations to high $\mathrm{O}_{2}$, low $\mathrm{CO}_{2}$ conditions. Photosyn. Res. 2013, 117, 121-131.

158. Watanabe, C.K.; Sato, S.; Yanagisawa, S.; Uesono, Y.; Terashima, I.; Noguchi, K. Effects of elevated $\mathrm{CO}_{2}$ on levels of primary metabolites and transcripts of genes encoding respiratory enzymes and their diurnal patterns in Arabidopsis thaliana: possible relationships with respiratory rates. Plant Cell Physiol. 2014, 55, 341-357.

159. Fukayama, H.; Sugino, M.; Fukuda, T.; Masumoto, C.; Taniguchi, Y.; Okada, M. Gene expression profiling of rice grown in free air $\mathrm{CO}_{2}$ enrichment (FACE) and elevated soil temperature. Field Crops Res. 2011, 121, 195-199.

160. Markelz, R.C.; Lai, L.X.; Vosseler, L.N.; Leakey, A.D. Transcriptional reprogramming and stimulation of leaf respiration by elevated $\mathrm{CO}_{2}$ concentration is diminished, but not eliminated, under limiting nitrogen supply. Plant Cell Environ. 2014, 37, 886-898.

161. Way, D.A.; Oren, R.; Kroner, Y. The space-time continuum: the effects of elevated $\mathrm{CO}_{2}$ and temperature on trees and the importance of scaling. Plant Cell Environ. 2015, 38, 991-1007.

162. Apel, K.; Hirt, H. “Reactive oxygen species: metabolism, oxidative stress, and signal transduction,” Annual Rev. Plant Biol. 2004, 55, 373-399. 
163. Hossain, M.A.; Bhattacharjee, S.; Armin, S. “Hydrogen peroxide priming modulates abiotic oxidative stress tolerance: insights from ROS detoxification and scavenging," Frontiers in Plant Sci. 2015, 6, 420.

164. Gupta, D.K.; Pena, L.B.; Romero-Puertas, M.C. “NADPH oxidases differentially regulate ROS metabolism and nutrient uptake under cadmium toxicity," Plant Cell \& Environ. 2016, 40, 4.

165. Elstner, E.F. “Metabolism of activated oxygen species," in The Biochemistry of Plants: A Comprehensive Treatise, D. D. Davies, Ed., Elsevier 1987, 8 , 253-315.

166. Noctor, G.; Mhamdi, A.; Foyer, C. H. The roles of reactive oxygen metabolism in drought: not so cut and dried. Plant Physiol. 2014, 164, 16361648.

167. Carvalho, M.H.C. Droughty stress and recative oxygen species, production, scavenging and signaling. Plant Signal Behav. 2008, 3, 156-165.

168. Biehler, K.; Fock, H. Evidence for the contribution of the Mehler-Peroxidase reaction in dissipating excess electrons in drought-stressed wheat. Plant Physiol. 1996, 112:265-272.

169. Noctor, G.; Veljovic-Jovanovic, S.; Driscoll, S.; Novitskaya, L.; Foyer, C.H. Drought and oxidative load in the leaves of Cз plants: a predominant role for photorespiration? Ann Bot. 2002, 89, 841-50

170. Bose, S.; Du, Y.; Takhistov, P.; Michniak-Kohn, B. “Formulation optimization and topical delivery of quercetin from solid lipid-based nanosystems," Int. J. Pharmaceutics 2013, 441, 56-66.

171. Mittler, R. ROS are good. Trends Plant Sci. 2017, 22, 11-19.

172. Awasthi, R.; Bhandari, K.; Nayyar, H. Temperature stress and redox homeostasis in agricultural crops. Front. Environ. Sci.2015, 3, 11.

173. Choudhary, F.K.; Rivero, R.M.; Blumwald, E.; Mittler, R. Reactive oxygen species, abiotic stress and stress combination. 2016, DOI: https://doi.org/10.1111/tpj.13299.

174. Catalá, A.; Díaz, M. Editorial: impact of lipid peroxidation on the physiology and patho-physiology of cell membranes. Frontiers in Physiol. 2016, $7,423$.

175. Gaschler, M.M.; Stockwell, B.R. Lipid peroxidation in cell death, Biochem. E Biophysical Res. Comm. 2017, 482, 419-425.

176. Reginato, M.; Varela, C.; Cenzano, A.M. Role of polyphenols as antioxidants in native species from Argentina under drought and salinization. In Reactive Oxygen Species and Oxidative Damage in Plants Under Stress, D. Gupta, J. Palma, and F. Corpas, Eds., Springer, Cham, Switzerland, 2015, pp. 247-267.

177. Mattos, L.M.; Moretti, C.L. Oxidative stress in plants under drought conditions and the role of different enzymes. Enzyme Eng. $2015,5,1$.

178. Sharma, M.; Gupta; S.; Deeba; F. Effects of reactive oxygen species on crop productivity: an overview. In Reactive Oxygen Species in Plants, V. P. Singh, S. Singh, D. K. Tripathi, S. M. Prasad, and D. K. Chauhan, Eds., John Wiley \& Sons Ltd., 2017.

179. Park, H.J.; Lee, A.; Lee, S.S. Over expression of golgi protein CYP21-4s improves crop productivity in potato and rice by increasing the abundance of mannosidic glycoproteins. Frontiers in Plant Sci. vol. 2017, 8, 1250.

180. Yin, X.; Xie, X.; Xia, X. Involvement of an ethylene response factor in chlorophyll degradation during citrus fruit degreening. The Plant J. 2016, $86,403-412$.

181. Xie, X.L.; Xia, X.J.; Kuang, S. A novel ethylene responsive factor CitERF13 plays a role in photosynthesis regulation. J. Plant Sci. 2017, 256, 112119.

182. Shumbe, L.; Chevalier, A.; Legeret, B.; Taconnat, L.; Monnet, F.; Havaux, M. Singlet oxygen-induced cell death in arabidopsis under high-light stress is controlled by OXI1 kinase. Plant Physiol. 2016, 170, 1757-1771. 